This is an author produced version of a paper published in Scandinavian Journal of Forest Research.

This paper has been peer-reviewed and is proof-corrected, but does not include the journal pagination.

Citation for the published paper:

Gun Lidestav. (2010) In competition with a brother: Women's inheritance positions in contemporary Swedish family forestry. Scandinavian Journal of Forest Research. Volume: 25, Number: Supplement 9, pp 14-24. http://dx.doi.org/10.1080/02827581.2010.506781.

Access to the published version may require journal subscription. Published with permission from: Taylor \& Francis.

Standard set statement from the publisher:

This is an Author's Accepted Manuscript of an article published in SCANDINAVIAN JOURNAL OF FOREST RESEARCH, 12 Aug 2010, copyright Taylor \& Francis, available online at: http://www.tandfonline.com/10.1080/02827581.2010.506781.

Epsilon Open Archive http://epsilon.slu.se 


\title{
In competition with a brother - Women's inheritance positions in contemporary Swedish family forestry
}

\author{
GUN LIDESTAV ${ }^{1}$ \\ Department of Forest Resource Management, Swedish University of Agricultural Sciences, \\ SE-901 83 Umeå,
}

\begin{abstract}
Swedish family forestry is characterized by traditional perceptions of the farm as a project that spans over generations and a strong desire to preserve family ownership in accordance to a paternal inheritance tradition. In this study women's inheritance positions in contemporary family forestry in Sweden were examined by using three different sources (i) a national register of all forest owners (ii) an inquiry study and (iii) narrative accounts from female forest owners. An asymmetric ownership pattern is exposed in the analysis of all three materials. Gender certainly has an impact on who, what, and how family owned forest land is transferred from one generation to another. Furthermore, the analysis of the narrative accounts shows that a minority of the women correspond to the concept transitive element. A typology with three additional concepts namely transitive agent, transformative element and transformative agent, is therefore suggested and discussed.
\end{abstract}

Keywords: Data triangulation, gender, typology

\footnotetext{
${ }^{1}$ Correspondence: G. Lidestav, Dept of Forest Resource Management, Swedish University of Agricultural Sciences, SE-901 83 Umeå, Sweden E-mail: gun.lidestav@srh.slu.se
} 


\section{Introduction}

An essential question in most farming societies is the transfer of the farm - the land as well as buildings and movable property - from one generation to the next. The conflicting interests of keeping the often hard-won property intact, yet giving one's offspring the best possibilities to earn their own living, have to be dealt with (Lövgren, 1987). Depending on natural, social and demographical conditions for production as well as basic ideas on how rights and responsibilities should be divided between individuals and the collective (e.g. family), different solutions for this conflict have developed (Wennersten, 1995). Two main principles are discernible; the principle of real estate or equal rights, and the right of primogeniture (Sporrong, 1995a). The principle of real estate gives all siblings inheritance to some of the real estate. These parts can be of equal or different size or value, and can either be divided into individual lots or remain as defined parts in an undivided estate. In regions with a diversified economy, the principle of real estate has generally been used. Where agriculture have been dominating the economy, particularly in regions with a feudal system, the principle of primogeniture on the male side have usually been practiced (Sporrong, 1995b).

Within contemporary Swedish family forestry, which has a common history with family farming in a traditional farmer's society, there is still a strong interest for keeping the farm in hands of the family (Törnqvist, 1995; Flygare, 1999, Nordström Källström, 2008). However, co-ownership has become more and more usual. Preserving the property is a principal goal for most owners. In many cases the property represents not only economical values and tangible assets, but also a social and cultural heritage that deserves to be transferred to the next generation (Westholm, 1992). According to Törnqvist (1995) the property should be regarded as an arena with a strong social, cultural and economical meaning, surrounded by corner-stones of livelihood, work, residence and valuations. All together, such a property constitutes "a project that spans generations". The ownership itself and its assignment of accumulated capital and work are linked to a transfer of knowledge, experience of practical work, ability to manage the property, as well as the transfer of a lifestyle. In order to take, and keep a position in forest ownership the individual's situation must be in accordance with the economical and ideological conditions of the structure that precedes the individuals who live within it (c.f. Giddens theory of structuration, Giddens, 1990). However, the reproduction and transformation of structures are set by individuals and their actions (Törnqvist, 1995). To understand better the structure and its persistence and flexibility, Lidestav and Nordfjell (2005) developed a "cob-web model". In this model (Figure 1) land is considered as the basic resource around which work and family life is organized. With land follows property rights, which through inheritance are transferred to the children, being a result of marriage. Work has to be invested in order to obtain revenue from the capital invested or to develop the value of the property. The returns and value increment can be charged by taxes. Together with specific ideas on what constitutes a proper forest owner the prevailing gender contract has an impact on how work is divided and remunerated, on inheritance position and on marriage. With the gender contract concept regarded as an ideal type, a theoretical basis for understanding and the immobility that characterize the conditions and tendencies of women and men throughout history is established (developed by the Swedish historian Yvonne Hirdman, e.g Hirdman, 2003). This contract consists of a three distinctive principles claiming that 1) men/masculinity and women/femininity should be kept apart 2) male dominance and female sub ordinance and 3) that both women and men are implicated in the production and reproduction of the gender order. Further, the gender contract contains rules, norms, customs and expectations on the rights, duties and responsibilities of men and women. The role of the 
man is to be breadwinner and protector, while the woman should take care of the children and their upbringing. Before any alteration in the gender contract can take place, the

circumstances must have changed in such a way that it no longer is perceived rational to uphold the tradition. (Hirdman, 2003). By treads of traditions, or rather a fine-meshed net of social practices, the above mentioned formal and informal institutions are brought together into a field of social reality (c. f. Bourdieu, 1986) within which the forest owner exist. Thus, " the model should be comprehended as both giving structure to forest owners' actions and social practices and showing how identities and social practices are constructed” (Lidestav and Nordfjell, 2005, p 399).

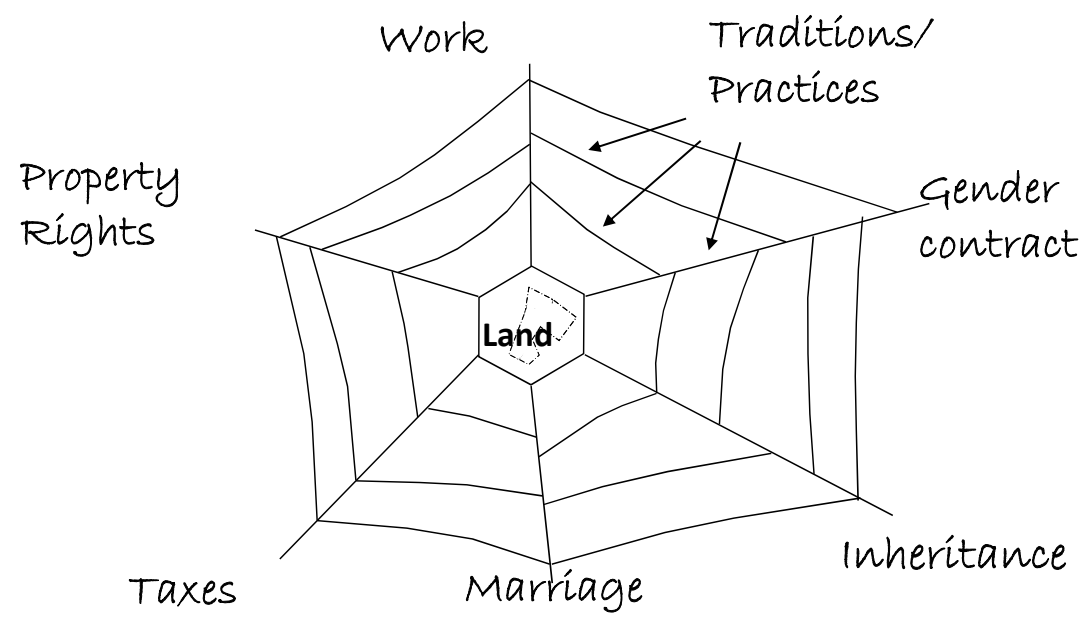

Figure 1. The "cobweb” model for understanding social practices in family forestry (modified version of the model presented in Lidestav \& Nordfjell, 2005)

Women in Sweden have, as far as we know, never been excluded from the right to inherit land (Sawyer, 2003). However, their rights of disposition to the land and the profits from it, was not fully and legally recognized until half a century ago (Niskanen 2001). The husband's exclusive right to manage his wife's land, as the general rule before the introduction of the new Marriage Act in 1921, was due to certain provisional regulations regarding marriages predating 1921 and left in function until 1950. According to Niskanen (2001), women as daughters or wives are carriers of an "inert" property right, which can only be executed in the absence of a man. It is inert in the sense that it transfers different elements of the other components of property rights, by marriage or inheritance, from one man to another, usually her father to her husband or son.

The presence of such an inert property right is in line with Flygare's (1999) description of how farms in two Swedish grain-growing districts are transferred from one generation to the next. However, while Niskanen (2001) argues that the idea of family farming as a male operation is based on this inert property right, Flygare sees the reverse relation. According to 
Flygare (1999), inheritance positions are established in everyday work, and the ownership is justified by the work invested in farming, particularly in the field work. As long as women's contribution to the farm, viewed in broad terms of living and means of support of the family, consists mainly of other tasks than fieldwork, they can never compete with a man regarding property acquisition. A woman's chance of receiving a farm depends on being born in a family with no sons, marrying a farmer, or becoming the widow of a farmer (Flygare, 1999).

The transfer of farms in the contemporary Swedish society is still characterised by a patrilinear gender order, implying that women's land ownership depends on whether a man lays claim to the same property or not. (To understand the transfer of farms from one generation to another Flygare refers to Laqueurs "single sex model”.) To maintain this patrilinear gender order, women in their role as mothers and grandmothers are at least as involved as the men. By identifying the most interested and appropriate son, and presenting stories on his proven ability in work, the patrilinear inheritance system is justified. To clarify women's function in the transfer of family farms, Flygare (1999) introduces the concept transitive element. In a later work (Flygare 2001) she chooses to label these women's relation to the farm as transitive agents, arguing that they themselves are acting to maintain the patrilinear inheritance system. However, as they are acting in accordance to an expected norm and based on the prevailing gender order, I find transitive element to be a more adequate label.

Similar results are presented by Haugen (1994) in a Norwegian study on inheritance positions. Farmers' daughters, who in accordance to the Allodial Law have the best inheritance position, are in many cases expected to waive their claims on the farm in favor to a younger brother. (By an amendment to the Allodial Law in 1974, the eldest child now got priority to the family farm, instead of the eldest son which was the previous rule). When it comes to identifying "the proper heir", i.e. the younger brother, mothers and grandmothers plays an important role.

Considering the common history of family farming and family forestry in Sweden ( e. g. Törnqvist, 1995) it seems likely that women's possibilities to become forest owners are limited in a similar way. Contrary to this assumption is, however, the fact that $37 \%$ of the forest owners in Sweden are women, and in addition the share of female owners is much higher on forest properties with no agricultural farming than on properties with combined production (Lidestav and Nordfjell, 2005). Furthermore $39 \%$ of all female forest owners own together with their spouse, $36 \%$ together with relatives while $20 \%$ are single owners (Lidestav and Nordfjell, 2005). In other words it is unlikely that women's forest ownership can be explained solely by either marriage to a man that has inherited forest land, their husband's death or being born in a family of only daughters.

With this background the inheritance pattern in contemporary family forestry in Sweden was studied, with the aim to examine the extent of women's ownership, and by which conditions female heirs can compete with a brother or other male relative. The specific research question concerns the impact of gender on (1) the take over as such and the conditions of forest property transfer (2) the ownership constellation, i.e. single or jointly owned, and (3) the size of the property. Furthermore, female forest owners' participation in the process of transferring forest property and forestry management traditions, linked to the project that spans generations (cf. Törnqvist, 1995), were examined in relation to the transitive element concept (cf. Flygare, 1999).

As a point of reference, some basic characteristics of women's forestry ownership compared to men's, irrespective of how the property has been acquired, were established. 


\section{Materials and methods}

Three different sources of data, primarily recorded for other purposes, were used, separately and in conjunction, to gain knowledge on the inheritance pattern in Swedish family forestry. Two of them, a register material and inquiry study material, consist of quantitative data only, while the third one also contains qualitative data.

To describe women's and men's forestry ownership in general, a national register of forest estates and forest owners (Skogsdataregistret, 1994) was used, from which all physical persons between the age of 18 and 80 years who are recorded as owners of at least 5 ha forest land were selected. This selection served the purpose to produce a register or sampling frame convenient for an inquiry study focusing on forest owners as individuals without the kind of gender bias (underestimation of female owners) characterizes inquiry studies based on a sampling procedure with the property (management unit) as the sampling unit.

The inquiry study, performed from November 1997 - January 1998 by a mail questionnaire, was directed to a stratified sample of 1250 male and 1250 female forest owners. From the 1608 respondents 980 were selected, as they where owners to a forest property that they had acquired by their own parents or other relatives. Mean values and proportions, regarding to who, what, and how, family forests are transferred to male respectively female heirs was estimated .To clarify if there were significant differences between women and men, differences between means at 5\% confidence level were assessed. However, from the material it could not be determined to if the respondent had outrivaled a brother or sister.

The 116 narratives accounts collected in 1999 were analysed to find information on the extent to which, and under which circumstances daughters could compete with a brother. The call for narrative accounts was published in some of the largest magazines in Sweden, the weekly magazine Land Familj and the magazine of the Federation of the Forest Owners Associations, Vi Skogsägare. In addition the networks Women in Forestry and Black Woodpecker were used for distribution of off prints. The call was also distributed at the ELMIA Wood exhibition in June 1999, the Forestry Museum in Lycksele and the archive of the Nordic Museum in Stockholm. (Forest Museum in Lycksele also hold the archive by the name Skogsägande Kvinnors Berättelser, SLU, 1999, referred to as SKB, 1999). Together with the call there was a guideline with a number of questions, asking female forest owners about themselves, their relation to the forest land, and their role as forest owner in relation to their children, the forestry sector and the society. The length and the content of the accounts varied wiedly,, from half a handwritten page just referring to one or two of the issues in the guidelines, to more then 10 typed pages dealing with most of the questions raised. A typical reply comprised of some 3-4 pages focusing on some of the issues, with a private touch. Some women seemed to be keen on expressing themselves in written language, and had obviously spent some time on the layout. In some cases photographs or paintings, even recipes for their favourite jam made from wild berries, had been added. Other women have written their stories instantaneously or in-between other demanding tasks.

The material has earlier been subjected to an analysis of cultural themes (Lidestav et al 2000, Lidestav \& Engman 2000). Three of the six major themes then reported, were of particular interest in this study, namely; In the chain of generations, Ownership, relations and sense of fellowship, and To be a woman and forest owner. (The other themes are Forestry, Experiences of nature, Knowledge, transfer of traditions and role models). The cultureanalytical approach was applied further, as it offers a way of dealing with details and meaning in order to create explanatory models of the relation between these details ( Ehn \& Löfgren, 1982). 


\section{Results}

\section{Asymmetrical ownership conditions}

When the material based on the national register of forest estates and forest owners was analysed, an asymmetrical distribution of women's and men's forest ownership appears. Differences are displayed in terms of the property size as well as ownership category (Table I). The total number of male owners is 202, 534, and the number of female owners is 119 , 705. When a forest property is owned by two or more persons of different gender, women amount to almost half of the owners irrespective of property size. In contrast, when a woman was a single owned or owns together with other women only, the proportion of female ownership decreased as the size of the property increased. Women's ownership of forest land is, in other words, characterized by partner ownership with at least one man. Examining the figures presented in Table I according to the restricted modes of entry into position that Flygare (1999) describes, leads to the interpretation that half of the women own their properties together with their husband, while slightly more than a quarter are daughters without a brother in the family. The rest would appear be widows and daughters of single child families. Unfortunately there are no records of civil status or family relation to eventual partner ownerships in the register, nor any records of how the property has been acquired, which could be used to support or reject such an interpretation.

Table I. Proportion (\%) of female forest owners in different ownership categories,.

\begin{tabular}{l|cccc}
\hline & $\begin{array}{c}\text { Single } \\
\text { owned }\end{array}$ & $\begin{array}{c}\text { Owned together } \\
\text { with one or more } \\
\text { persons of same sex }\end{array}$ & $\begin{array}{c}\text { Owns together with } \\
\text { one or more persons } \\
\text { of different sex }\end{array}$ & All \\
\hline $5-49$ ha & 26 & 30 & 49 & 37 \\
$50-399$ ha & 20 & 26 & 49 & 37 \\
400 ha - & 17 & 19 & 48 & 37 \\
All & 24 & 29 & 49 & 37 \\
\hline
\end{tabular}

Note; Source: Skogsdataregistret (Statistics Sweden, 1994).

However, from data collected in the inquiry survey, the number of male owners that have taken over the forest land from their own parents (relatives) was estimated to some 135,000 persons or $67 \%$ of the male compared to 71,000 female owners (or $59 \%$ ) that have taken over from their parents. Further, the male heirs have acquired 92,167 management units and the female owners 37,538 units. In conclusion, a majority of women have become forest owners by acquisition from their own family/relatives and not by marriage and via the husband's family. Among male owners, acquisition from own family/relatives was ever more common. As presented in Table II, it is also more common that male owners are single owners (39\%) compared with female owners (25\%). The proportion of women among single owners is estimated to $25 \%$, which is almost the same as reported in the previous analysis of Skogsdataregistret (Table I). Half of these women and a third of these men own properties together with siblings or other relatives and women are more likely to own together with male relatives then men with female relatives. The proportion that owns together with a spouse is estimated to $24 \%$ for men and $22 \%$ for women. However, when comparing sample records of ownership constellation with the answers given by the respondents, a significant discrepancy is found. Approximately 14, 400 (11\%) of the male owners that reports that they own the forest land together with their wife are registered as single owners. Corresponding figures for 
female owners are 1300 (2\%). This discrepancy is interpreted thus: when women are single owners they usually own the estate as personal property, while men's ownership is more often held jointly with their wife.

Table II. Proportion of male and female owners on forest properties acquired via their own parents/relatives by ownership constellation $(n=980)$.

\begin{tabular}{l|cccc}
\hline & $\begin{array}{c}\text { Men } \\
\text { (row \%) }\end{array}$ & $\begin{array}{c}\text { Women } \\
\text { (row \%) }\end{array}$ & $\begin{array}{c}\text { Men } \\
\text { (column \%) }\end{array}$ & $\begin{array}{c}\text { Women } \\
\text { (column \%) }\end{array}$ \\
\hline Own alone & $75 \mathrm{a}$ & $25 \mathrm{~b}$ & $39 \mathrm{a}$ & $25 \mathrm{~b}$ \\
Own together with spouse/partner & $68 \mathrm{a}$ & $32 \mathrm{~b}$ & $24 \mathrm{a}$ & $22 \mathrm{a}$ \\
Own together with siblings/relatives & $57 \mathrm{a}$ & $43 \mathrm{~b}$ & $34 \mathrm{a}$ & $50 \mathrm{~b}$ \\
$\quad$ - with same gender & $63 \mathrm{a}$ & $37 \mathrm{~b}$ & $14 \mathrm{a}$ & $16 \mathrm{~b}$ \\
$\quad$ - with different gender & $53 \mathrm{a}$ & $47 \mathrm{~b}$ & $20 \mathrm{a}$ & $34 \mathrm{~b}$ \\
$\begin{array}{l}\text { Own together with non-relatives or other } \\
\text { combination }\end{array}$ & $62 \mathrm{a}$ & $38 \mathrm{~b}$ & $3 \mathrm{a}$ & $3 \mathrm{a}$ \\
\hline
\end{tabular}

Note: In raw lines differences between means (at the 5\% level) in the two left hand columns respectively the two right hand columns are indicated by the letters a and b.

From the material it cannot be determined how many of the 71,000 female owners have a brother with whom they have competed. What we do know is that at least 23,200 women have a brother or male relative as partner-owner. It is likely that there are a number of woman who own alone or together with another woman, who also have outrivaled a brother. However, such information is not included in the inquiry material. By comparing some other variables, interesting information can be obtained. Regarding mean age and proportion of married, no significant differences between men and women were found (Table III). This indicates conformity between the genders regarding generational belonging and family patterns. However, the mean size of women's forest property is lower, and the average number of owners per estate higher. Female owners are less often residents on the estate and agricultural farmers. Furthermore they have more often acquired the forest land as a gift or by inheritance, while the male owners more often have bought the property from their parents.

Table III. Descriptive accounts of owners and forest estates that have been acquired via parents/relatives $(n=980)$

\begin{tabular}{l|cc}
\hline & Men & Women \\
\hline Mean size (ha) & $58.2 \mathrm{a}$ & $49.4 \mathrm{~b}$ \\
Mean age (years) & $53.0 \mathrm{a}$ & $52.3 \mathrm{a}$ \\
Proportion with spouse (\%) & $80 \mathrm{a}$ & $83 \mathrm{a}$ \\
Proportion resident at the estate (\%) & $51 \mathrm{a}$ & $31 \mathrm{~b}$ \\
Proportion running agriculture on the estate (\%) & $34 \mathrm{a}$ & $16 \mathrm{~b}$ \\
No. of owners on the estate (mean) & $1.5 \mathrm{a}$ & $1.9 \mathrm{~b}$ \\
Taking over by inheritance/gift/last will (\%) & $42 \mathrm{a}$ & $61 \mathrm{~b}$ \\
Taking over by purchase from relatives (\%) & $59 \mathrm{a}$ & $39 \mathrm{~b}$ \\
\hline
\end{tabular}

Note: In raws differences between means (at the $5 \%$ level) in the left and right column are indicated by the letters a and $b$. 
Although there is a significant number of women that are forest owners in spite of brothers or other male relatives in the family, gender has an impact on (1) whether an heir has taken over the family forest farm or not (2) whether the forest estate is single or jointly owned (3) the size of the property, and the conditions of the transfer i. e. by inheritance/gift/last will or purchase.

\section{Gendered inheritance positions}

The alternation of generations is, as previously mentioned, a long term process where the children successively become aware of the expectations of the grandparents or parents, in either on taking over the property or waiving the claim in favor of another sibling. To what extent these expectations are put in plain terms or just implied may differ between families. However, it seems as the children generally recognize the one chosen including the reasons for this, as well as who and why the others are expected to give up the farm (Flygare 1999, Haugen 1994, Törnqvist 1995). The discussion of expectations and decisions prior to the transfer seems to be kept within the family. The narrative accounts that were recorded in 1999 could therefore be expected to give some information on to what extent and by which circumstances daughters could compete with a brother.

The initial analysis showed that 74 out of 116 women had acquired the forest land via their own parents/relatives and in 30 cases one or more brothers is also mentioned. Within each of these three groups ownership constellations differ, but a common feature is that ownership together with husband is less frequent than single ownership (Table IV). Ownership together with relatives is most common among those women that have mentioned a brother. The lower number of joint ownerships with siblings/relatives in the other groups may reflect the appearance in in these groups of women who are the only child of a family.

Table IV. Number of narrators by forest ownership constellation

\begin{tabular}{l|cccc|}
\hline & Owns alone & $\begin{array}{c}\text { Owns } \\
\text { together } \\
\text { with spouse }\end{array}$ & $\begin{array}{l}\text { Owns } \\
\text { together } \\
\text { with sibling/ } \\
\text { relatives }\end{array}$ & $\begin{array}{c}\text { No } \\
\text { information }\end{array}$ \\
\hline All narrators $(n=116)$ & $52^{\mathrm{a}}$ & 24 & 29 & 14 \\
$\begin{array}{l}\text { All of those that have acquired by their own } \\
\text { family }(n=74)\end{array}$ & $39^{\mathrm{b}}$ & 12 & 25 & \\
$\begin{array}{l}\text { All of those who have outrivaled a } \\
\text { brother/male relative }(n=30)\end{array}$ & $12^{\mathrm{b}}$ & 5 & 15 & \\
\hline
\end{tabular}

${ }^{\mathrm{a}}$ whereof three people own one part of the forest holding alone and another part together with husband or relatives ${ }^{b}$ of which two people own one part of the forest holding alone and another part together with husband or relatives.

A further analysis of the 30 narrative stories with a brother is mentioned, displays 12 cases in which the brother has not received any forestland at all (I) (Table V). In two of these cases the narrators' husbands are mentioned as partner-owner. Four other cases display a situation where daughters have taken over a forest holding themselves, but the brothers have at the same time or previously acquired another forest property of equal or larger size (II). In one of 
these cases a son is mentioned as partner-owner, probably as a result of a partner ownership with the woman's husband before she become widow. Finally there are 14 cases where the transfer took place together with one or more brothers, sometimes in combination with another sister (III). The present absence of male-partner owners in three of the cases is probably due to the death of the brother after the transfer.

Descriptive accounts of the individual women and their relation to the forest holding, gives an understanding of the extent and nature of their incorporation in "the project that spans generations” (cf. Törnqvist, 1995). The age of the women ranges from 22 to 73 years and the size of the farm from 3 to 450 hectares. Twenty of the women are married and all except four have children. Eleven of the women live on the property and seven of them do agricultural farming as well. Regarding administrative and practical forestry work, 21 of them do either or both. Further details are given in Table V. In addition, the reasons given by the narrators for being the one who acquired the forestland is considered as significant. The reasons are either in some way connected to the narrator's own relation to the forest land (A) or technical in the sense that it is beyond the influence of the individual (B). More specifically the reasons can be expressed in the following categories:

- A1 - Being the one that has demonstrated more or at least as much interest/commitment in the forest farm, or the lack of interest/commitment of the brother.

- A2 - Being the one who live nearest to the forest farm, the one who was prepared to settle and maintain the farm and/or support the parents' residence.

- A3 - Being married to a handy man.

- B1 - Fiscal reasons.

- B2 - A solution to the equity problem; giving all children the same economic conditions if other means of compensation are regarded as less convenient or impossible due to the high market value of the property, or the brother had already acquired another forest farm.

- B3 - Being the one who happened to be at hand when the transfer was settled owing to the sudden death of the father/parents, a very young or sick brother.

The predominant reasons given are A1 (13 times) and B2 (14 times) and many narrators express more than one. In four narrations no reason at all is given.

\section{From transitive element to transformative agent}

The culture analysis shows that female forest owners can relate to the forest ownership, as well as the possibilities and restrictions shaped by traditional and gendered ideas of being a forest owner, in other ways than the concept of "transitive element" introduced by Flygare (1999). There are certainly women trying to alter the norm by challenging the idea of forest management as "men's only" work. These women make decisions about the management, either by themselves or in co-operation with partner-owners, and are also performing different kinds of practical forest work. Some women express more of an individualistic view on the forest farm than an approach in line with the farm as "a project that spans generations" (cf. Törnqvist, 1995). 
Table V. Descriptive accounts of the individual women and her relation to the forest holding.

\begin{tabular}{|c|c|c|c|c|c|c|c|c|c|c|c|c|}
\hline ID. no & $\begin{array}{l}\text { Trans- } \\
\text { fer }\end{array}$ & Ownership & $\begin{array}{c}\text { Farm } \\
\text { size } \\
\text { (ha) }\end{array}$ & $\begin{array}{l}\text { Age, } \\
\text { (years) }\end{array}$ & $\begin{array}{c}\text { Civil } \\
\text { status }\end{array}$ & $\begin{array}{l}\text { Child- } \\
\text { ren }\end{array}$ & Resident & Farming & $\begin{array}{l}\text { Admin. } \\
\text { work }\end{array}$ & $\begin{array}{c}\text { Practical } \\
\text { work }\end{array}$ & Reason & Type \\
\hline 86 & I & Alone & 70 & 66 & Widow & Yes & Yes & No & Yes & ? & $\mathrm{A} 1, \mathrm{~A} 3$ & $\mathrm{TE}$ \\
\hline 21 & III & Brother & 50 & 35 & Married & No & No* & No* & No & No & B2 & $\mathrm{TE}$ \\
\hline 35 & III & Brother & 53 & 56 & Married & No & Yes & Yes & Yes & Yes & A1 & $\mathrm{TE}$ \\
\hline 59 & III & Sister in law & & 63 & Married & Yes & $?$ & No & $?$ & $?$ & $?$ & $\mathrm{TE}$ \\
\hline 113 & III & Siblings & 70 & 58 & Married & Yes & No & No & No & No & B2? & $\mathrm{TE}$ \\
\hline 116 & III & Brother & & 62 & Alone & Yes & Yes & Yes & $?$ & Yes & $?$ & $\mathrm{TE}$ \\
\hline 67 & $\mathrm{I}$ & $1 / 2$ alone, $1 / 2$ husband & & 36 & Married & Yes & Yes & Yes & Yes & Yes & $\mathrm{A} 1, \mathrm{~A} 3$ & TA \\
\hline 12 & I & Alone & 63 & 38 & Divorced & Yes & Yes & Yes & Yes & Yes & A1 & TA \\
\hline 119 & I & Alone & & $\sim 45$ & Married & Yes & Yes & No & Yes & Yes & B3 & TA \\
\hline 109 & II & Son $(1 / 2)$ & 85 & 56 & Widow & Yes & Yes & No & Yes & Yes & A1, B2 & TA \\
\hline 13 & I & Alone & 300 & 49 & Partner & Yes & Yes & Yes & Yes & Yes & A2 & TA \\
\hline 16 & I & Alone & & $\sim 40$ & Married & Yes & No & No & Yes & Yes & $?$ & TA \\
\hline 77 & III & Sister in law & 120 & 43 & Married & Yes & No & No & Yes & Yes & B2? & TA \\
\hline 110 & II & Alone? & 50 & 52 & Partner & Yes & No & No & Yes & No & B1, B2 & TFE \\
\hline 19 & III & Brother \& sister & 3 & 22 & Alone & No & No & No & $?$ & Yes & B2, B3 & TFE \\
\hline 33 & III & Brother & 70 & 55 & Married & Yes & No & No & Yes & Yes & $\mathrm{A} 1, \mathrm{~B} 2$ & TFE \\
\hline 42 & III & Sisters \& brother & 450 & 54 & Married & Yes & No & No & Yes & No & B2 & TFE \\
\hline 24 & $\mathrm{I}$ & Alone & 20 & 66 & Married & Yes & Yes & Yes & Yes & Yes & A2, B3 & TFE \\
\hline 84 & III & Sister (brother ill) & & 60 & Married & Yes & No & No & No & No & A1, B2 & TFE \\
\hline 51 & I & Husband & 55 & 44 & Married & Yes & No & No & $?$ & $?$ & $?$ & TFE \\
\hline 114 & III & Brother & & 52 & Married & No & No & No & Yes & $?$ & $\mathrm{~A} 1, \mathrm{~B} 1, \mathrm{~B} 2$ & TFE \\
\hline 108 & II & Alone & & 59 & Married & Yes & No* & No* & Yes & Yes & B2 & TFE \\
\hline 88 & I & Alone & 103 & 65 & Married & Yes & No & No & $?$ & Yes & B1?, B2? & TFA \\
\hline 5 & I & Sister & $\sim 130$ & 50 & Married & Yes & No & No & Yes & Yes & $?$ & TFA \\
\hline 27 & II & Alone & & 73 & Widow & Yes & Yes & No & Yes & Yes & $\mathrm{A} 1, \mathrm{~B} 2$ & TFA \\
\hline 11 & III & Brother & 110 & 61 & Married & Yes & No & No & No & Yes & A1, B2 & TFA \\
\hline 80 & III & Brother & & $\sim 30$ & Married & Yes & Yes & Yes & Yes & Yes & A1 & TFA \\
\hline 102 & III & Brother & & 55 & Alone & Yes & No & No & Yes & Yes & $\mathrm{A} 1, \mathrm{~B} 2$ & TFA \\
\hline 95 & I & Alone & 14 & 44 & Married & Yes & No & No & Yes & No & A3 & TFA \\
\hline 75 & $\mathrm{I}$ & Alone & 60 & 42 & Alone & Yes & No & No & Yes & Yes & A1 & TFA \\
\hline
\end{tabular}

* on her husbands farm 
The narratives can be arranged in an interpretation model or typology, where the forest farm constitutes the fundamental condition, and the transitive element concept forms one extreme position (Figure 2). The opposite position is named transformative agent and in between there are transitive agents and transformative elements. In this model the concept pair element - agent refers to whom set the role the women play; either a role that has been given to them by others or the circumstance and that they will play as long as required, or a role that they have choose themselves. The concept pair transitive - transformative, refers to how they play the role, the "performance" so to say; either in accordance to a traditional forest owner ideal, which implies that the owner do most of the forestry operations himself or herself, or where new terms are set for operating the forest farm. However, these positions must be regarded as ideal type positions, and the following examples with quotations as most evident. (A descriptive compilation is presented in Table V)

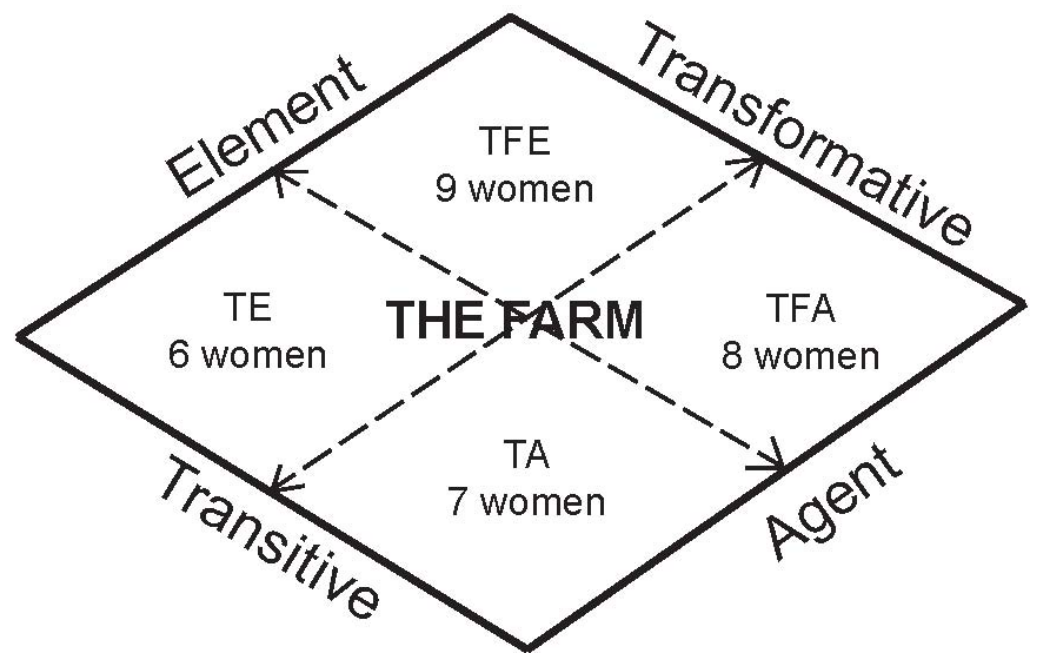

Figure 2. Suggested typology of female forest owners who have acquired a forest property from their parents/relatives in competition with a brother $(n=30)$. TE= transitive element; $\mathrm{TA}=$ transitive agent; $\mathrm{TFE}=$ transformative element; $\mathrm{TFA}=$ transformative agent.

\section{Transitive element}

This position is conditioned by "the project that spans generations" where a woman can be in charge when there is no man available but is expected withdraw as soon as there is one at hand. This study we certainly find women that are forest owners although there is or has been a brother, but they let male relatives and/or forest professionals undertake all the management, including decision making. In total six women express this position. One of them became owner of her parents' forest property of about 50 ha in 1991, since her mother had convinced her father to hand it over to the two children. By that time she was already married to a diary farmer in the neighborhood, while her brother was single and living in the province capital. As long as her father was alive, he was "the manager", making necessary contacts and discussing the management with her brother. Finally her opinion was asked for. According to her experience "it is no use ruminating or even planning, because what happens will happen, and it is not I, but others who decide...” Still for the future she hopes that her brother will buy 
her share of the forest farm, settle there, and "preserve it for the coming generations of our family...since my being sterile makes this impossible for myself to fulfill” (SKB, no. 21).

\section{Transitive agent}

This position is implies that a woman can replace a man in the "project that spans generations", if she acts as"a real man”, i.e. is operationally active in forest management. Such a position is taken by seven women. One of them was only 20 years old when she bought her parents forest farm (63 ha). At that time, she was not very interested in the management, but her brother even less so. Over time, she has developed a great interest and skill in forestry, and when she divorced she decided to keep the farm and learn to do as much as possible herself. "Living on a farm and managing it by your own, certainly has a major impact on one's life. The tasks differ and vary with the season. It is nice to be able to manage a farm and the forest for future generations. I want to hand it over to the one of my children who have the right feeling, interest, and who feel rooted.” Regarding her position as woman and forest owner she says: - " To be a woman and forest owner is to me much the same as being a man, I think, as I do typically male tasks.”(SKB, no. 12).

\section{Transformative element}

A woman in this position is conditioned by "the project that spans generations" in a way that permits her to relate to and act on the property in her own way. Nine women express this position. One of them was only 13 years old, she and her older sister and younger brother inherited a small woodlot from their grandfather. In her opinion, the small size makes it more comprehensible and interesting. It is mainly the forest as such, not the forestry that she finds interesting. "In contrast to the forestry concept, the forest means a lot in my life. To pick berries of every kind, and to make my way in rough terrain just to be able to sit down by a small fire and then turn back again, is something that I appreciate in my everyday life.” However, both she and her sister hope that their brother will buy their share when he becomes old enough. (SKB, no. 19).

\section{Transformative agent}

This position implies that the forest ownership is part of the own woman's individual life project, and it is only the individual possibilities and visions that set limits to what can or cannot be done. Women are able to change the role of a woman as well as the terms set for operation of the farm. Eight women express this position. One of them has been the owner of a rather large forest property, together with her sister, since the beginning of the 1990s. The property, which previously belonged to their father's parents, was handed over as a gift. She considers herself as a typical child of the 1940s.”All my life I have been quite independent and able to take care of my own interests. With new knowledge and experiences of different kinds on all the different places where I have lived, I see no end to what I can achieve in the future.” To her, the forest ownership is one of her many projects, as well as a means for her vision of gathering their rather spread-out family (her and her sisters, their grown-up children and their father). In this sense, it is still "a project that spans generations". However she runs the project, not the other way around, and she seems to have no expectations for the children to keep running her project after her, unless they really want to. "I thought that we together 
should have a permanent meeting place, created and developed by ourselves, something that we could gather around now and in the future. A place on earth with a little hut, built by all of us, and to which we all felt responsible for and involved in. This vision lasted for about two years when everything was new, but then reality appeared, and thinking, opinions, decisionmaking, responsibilities and involvement became more of a duty than a pleasure. This understanding has brought about a division of the property. In September, each of we sisters will have our own forest property, but the hut will be jointly owned. It is certainly the best solution that we could arrange by our own will, wish and pace.” (SKB, no. 5)

\section{Discussion}

It seems that a majority of the women that have acquired their forest land in competition with a brother, have a need to explain why the brother did not take over by himself or was even passed over. It is obvious that these women find their position as forest owners as odd, and something that has to be justified to others. This is generally done by expressing respect to "the common project that spans generation", in a number of ways. Fathers and sometimes mothers are mentioned as role models regarding knowledge, skill and management. Being the child who has demonstrated most interest and commitment in the management of the farm is another reason given. Furthermore the forest farm is commonly depicted as "their place on earth". However it has to be pointed out that in many of the 116 narrative stories, there are little or no information about the take over. Therefore it cannot be ruled out that there are other women in the material that have competed with a brother. If so, the crucial point is whether they do not comment on this because they consider it to be to private and emotional, or as a matter of course. To comprehend fully how the outcome of the transfer of the family forest farm is motivate, the often complex and long-lasting process that precede the transaction has to be uncovered by other and more anthropological oriented research methods, where parents as well as all the heirs are able to express their views. Further, collection of qualitative data should systematical cover the impact of all the institutions and social practices that makes up the field of social reality within which the forest owner exist (Figure 1).

The extent to which the narrators are representative for female forest owners in general and in particular women who have taken over from their parents in competition with a brother, cannot be fully determined. From a statistical point of view, these results only represent themselves. Those who have responded to the call are likely to be people with some kind of interest not only in the questions at issue, but also in writing and to have their answers read. However, it does not imply that they are underepresentative for female forest owners in other aspects. By comparing the narrative stories and results of the inquiry, it can be seen that the narrators own larger properties but are otherwise similar in terms of mean age, married proportion, having children, living on the property and being agricultural farmers. In the inquiry study as well as the narrative study, half of the women own holdings together with male relatives. However, the narrators are to larger extent single owners than the women in the inquiry study. Furthermore, the narrative stories correspond to a large extent with the inquiry results regarding the impact of gender in terms of the conditions for transferring the forest land from parents to children.

In spite of the asymmetric ownership exposed by all three analyses, viewed separately or in conjunction, it has become evident that sisters can compete with a brother in contemporary family forestry, even though brothers seldom are outrivaled. Joint ownership, by two or more siblings, may be regarded as a convenient solution to the both the traditional problem of not splitting up the holding as well as modern demands for gender equality. Compared to the 
rather unequivocal picture of daughter's inheritance positions presented by Flygare (1999), the situation within family forestry seems to offer female heirs better possibilities to own and manage the family property. In addition, family forestry appears to provide women some freedom to take alternative positions and develop their own individual role and relation to the property and the forest ownership. Although the number of female forest owners in the narrative accounts is limited, there are those who develop their role as women as well as the terms set to their family forest farming.

Expressed in terms of gender contract, it is likely that we are dealing with somewhat different gender contracts in family forestry compared to family agricultural farming as a result of that changes in circumstances ( Hirdman, 2004), with different routes being taken within family forestry and agricultural farming. One major plausible explanation could be found in the transformation of work done by the owner and his or her family. Agricultural operations are still dome by the farmer, but due to mechanisation of most of field work, tasks that previously was dome by women and children are now done by the single (male) farmer (Nordström Källström, 2008). In contrast, owing to the mechanization of forestry work, small-scale forest owners are nowadays usually contracting specialized forest companies (contractors) to do most of the harvesting and silvicultural operations that previously was done by the male owner (Follo 2008). This shift from self-employed in practical operations to management through others will according to Follo (2008) favour women's inheritance positions. However, she points out that a stronger policy and market emphasis on how to boost the production of timber and bioenergy from forest will probably increase competition between male and female heirs and in such situation the overall sub-ordinance of women and women's interest ( Hirdman, 2004) will become a drawback.

In conjunction, there appears to be an evident duality between individuals and structure, wherein the reflecting individual, through his or her actions, continuously reproduce the structures within family forestry. In this respect Giddens theory of structuration (Giddens, 1984), seems to offer a theoretical framework for further studies on the development of family forestry in modern societies, as he claims that all human actions involves structures and that these structures implies limitations as well as possibilities to the individuals. The typology proposed in this study, may then be used as a tool to explore the gender aspects of the duality.

\section{Acknowledgements}

The author thanks Ms Karin Engman for the initial selection and compilation of the narratives, and Professor Berit Brandth, PhD Anncristin Winroth, and MSc Patrik Häggqvist for providing valuable comments on earlier drafts of the manuscript. The study has been financed by the Royal Swedish Academy of Agriculture and Forestry (Gunnar and Birgitta Nordins fond and von Horns fond).

\section{References}

Bourdieu, P. (1986), Distinctions - A social Critique of the Judgement of Taste. London Taylor \& Francis.

Ehn, B. \& Löfgren, O. (1982), Kulturanalys. Ett etnologiskt perspektiv. [Culture analysis. An ethnological perspective] Stockholm: Liber 
Flygare, I. A. (1999) Generations and Continuity. Family Farming in Two Swedish Graingrowing Districts in $20^{\text {th }}$ Century. Dissertation. Upplands Fornminnesförenings Tidskrift 54. Upplands Fornminnesförenings Förlag. (In Swedish with English summary.

Flygare, I. A. (2001) Links, agents and alternatives. Generations of women in twentieth century agriculture. In B. Liljewall, K. Niskanen \& M. Sjöberg (Eds), Kvinnor och jord. Arbete och ägande från medeltid till nutid. [Women and the land. Work and ownership from the Middle Ages to present day] Skrifter om skogs- och lantbrukshistoria (pp 1330). Lund: Nordiska museets förlag.

Follo, G. 2008. Det norske familieskogbruket, dets kvinnlige og manlige skogeier, forvaltningsaktivitet - og metaforiske forbindelser. [ The Norwegian family forestry, its female and male management activity - and metaphorical connections] ( Doktorsavhandlinger ved NTNU 2008:173). Norges teknisk-naturvitensakplige universitet. NTNU-trykk. Trondheim. (In Norwegian)

Giddens, A. 1984. The Constitution of Soceity. Cambridge.

Giddens, A. 1990. The Consequences of Modernity., Cambridge: Polity press

Haugen, M. S. (1994) Rural Women's Status in Family Property Laws: Lessons from Norway. In S. Whatmore, P. Marsden \& Love, P. (Eds) Gender and Rurality. Critical perspectives on rural change series VI, pp. 87 - 101. London. David Fulton Publishers

Hirdman, Y. 2004. Genus - om det stabilas föränderliga former. [Gender - On the steady of the changable forms] (2nd ed. ) Malmö: Liber

Lidestav, G. \& Nordfjell, T. 2005. A Conceptual Model for understanding Social Practices in Family Forestry. Small-scale Forest Economics Management and Policy, 4:391 - 408

Lidestav, G., Wästerlund, D. \& Engman K. 1999. Self-conception and transfer of forest management tradition among female forest owners. In Furuberg, M, et al. (Eds) Proceedings Symposium on Women and Forestry, Lillehammer, Norway, August 1314, 1999. (pp 40-46). Oslo: LoboGrafisk,

Niskanen, K. (2001) The voice of the male dominaton. Marrige, property and gender during the first oart of the twentieth century. In B. Liljewall, K. Niskanen \& M. Sjöberg (Eds), Kvinnor och jord. Arbete och ägande från medeltid till nutid. [Women and the land. Work and ownership from the Middle Ages to present day] Skrifter om skogs- och lantbrukshistoria (pp 13-30). Lund: Nordiska museets förlag.

Nordström Källström, H. 2008. Between comfort and solitude. The social condtions at Swedish farms. Doctoral Thesis Acta Universitatis Agriculturae Sueciae. No 2008:74. Swedish University of Agricultural Sciences, Uppsala.. (In Swedish with summary in English)

Sawyer, B. (2003) Fromheten, familjen och förmögenheten. [The piety, the family and the property] In M. Ågren. M. (Ed) Hans och Hennes. Genus och egendom i Sverige från vikingatid till nutid. (pp 37-59.). Uppsala: Opuscula Historica Upsaliensia 30.

SKB (1999). Skogsägande Kvinnors Berättelser, SLU 1999. Skogsmuseet i Lycksele arkiv. Forest Museum in Lycksele Archive (un-published material)

Sporrong, U. (1995a) Avdelning I. In : U. Sporrong \& E. Wennersten (Eds). Marken, Gården, Släkten och arvet. Leksands sockenbeskrivning Del X. [The land, the farm, the kin and the inheritance. Leksamds Parish Account, Part X] Solna: Naturvårdsverket

Sporrong, U. (1995b) Avdelning III. In : U. Sporrong \& E. Wennersten (Eds). Marken, Gården, Släkten och arvet. Leksands sockenbeskrivning Del X. [The land, the farm, the kin and the inheritance. Leksands Parish Account, Part X] Solna: Naturvårdsverket

Statistics Swedens (1994) Skogsdataregistret. The Forestry computer file. (Un-published work up material). 
Törnqvist, T. (1995) Inhreritors of the woolands. A Sociological Study of Private, NonIndustrial Forest Ownership. (Report 41) Dissertation, Deptartment of ForestryIndustry-Market Studies, Swedish University of Agricultural Sciences Uppsala (In Swedish with an English summary)

Wennersten, E. (1995) Avdelning II. In : U. Sporrong \& E. Wennersten (Eds.) Marken, Gården, Släkten och arvet. Leksands sockenbeskrivning Del X. [The land, the farm, the kin and the inheritance. Leksands Parish Account, Part X] Solna: Naturvårdsverket Westholm, E. (1992) Modern land reforms in Dalarna, Sweden. Dissertation, Department of Social and Economic Geography Uppsala University. Geografiska Regionstudier 25. (In Swedish with English summary) 
